\title{
IMPLEMENTASI TOTAL QUALITY MANAGEMENT (TQM) DALAM BISNIS PENDIDIKAN
}

\author{
SAIFUL ANWAR \\ Dosen Pendidikan Ekonomi, Universitas Pamulang \\ dosen00902@unpam.ac.id
}

\begin{abstract}
ABSTRAK
Implementasi TQM telah menjadi sebuah kebutuhan yang cukup mendasar bagi sebuah lembaga pendidikan sebagai upaya dalam menjaga serta meningkatkan kualitas pendidikan. Penelitian ini memamparkan secara detail tentang penerapan manajemen mutu terpadu di institusi pendidikan, seluruh pembahasan secara mendalam tentang TQM berdasarkan analisis literatur terhadap 3 jurnal yang mewakili implementasi manajemen mutu terpadu (TQM) di berbagai jenjang pendidikan mulai dari pendidikan dasar (SD), pendidikan menengah (SMP-SMA) maupun pendidikan tinggi (universitas). Berdasarkan hasil penelaahan jurnal secara mendalam diperoleh sebuah fakta bahwa terdapat hal- hal yang dijadikan poin penting dalam pengejahwantahan manjemen mutu terpadu di institusi pendidikan yaitu: 1) kepemimpinan yang efektif; 2) berfokus pada kepuasan pelanggan; 3) peningkatan kualitas berkelanjutan; 4) komunikasi yang efektif dan 5) team work. Implementasi TQM disetiap jenjang pendidikan memiliki titik tekan yang berbeda-beda dalam setiap komponen TQM. penerapan TQM perlu ditopang dengan strategi-strategi implementasi yang baik serta teamwork yang solid diseluruh elemen sekolah.
\end{abstract}

Kata Kunci : Total Quality Management, Pendidikan 


\section{PENDAHULUAN}

Berbicara tentang TQM tidak akan terlepas dari akarnya yaitu berbicra terkait mutu, pada awalnya mutu sebuah produk selalu ditentukan oelh produsen, seberpa buruk maupun bagusnya suatu produk dapat dikatakan bermutu jika produsen tersebut mengatakan produk bermutu, tetapi pada perkembangannya sebuah produk dikatakan bermutu atau memiliki mutu ditentukan oleh konsumen atau pembeli. Produsen akan mengetahui bahwa produk itu bermutu jika konsumen membeli produk tersebut.

Perkembangan mutu terpadu atau TQM bermula dari buah pikiran tokoh-tokoh masyarakat bisnis di amerika serikat. Salah satu tokoh penting dalam teori mutu adalah edward deming yang sangat terkenal dengan konsep tentang mutu yaitu bahwa kualitas tidak ditentukan didalam toko tetapi diruang executive atau dapat dikatakan ditentukan sebelumnya.

Era informasi dan teknologi membuat kapasitas manajemen organisasi pendidikan melakukan transformasi menuju perubahan manajemen untuk menerapkan manajemen kontemporer yang dinamakan dengan Total Quality Management (TQM). TQM merupakan suatu pendekatan yang sebaiknya dilakukan oleh organisasi di era 4.0 untuk memperbaiki output, menekan biaya produksi serta meningkatkan produksi. Organisasi pendidikan yang merupakan perwujudan dari organisasi jasa diharapkan mampu mewujudkan kualitas sumber daya manusia melalui TQM yang berkualitas. Menurut Prabowo (2012) TQM dijabarkan sebagai sekumpulan prinsip dan teknik yang menitikberatkan terhadap peningkatan mutu dimana mutu tersebut harus bertitik tumpu pada institusi pendidikan secara berkelanjutan guna peningkatan kapasitas institusi tersebut untuk memenuhi kebutuhan serta keinginan siswa.

TQM (Sallis, 2006) adalah filosofi dan standar sebuah mutu sebuah organisasi pendidikan. sallis mengemukakan suatu filosofi alat yang digunakan untuk terus melakukan perbaikan mutu, tujuan tersebut dapat dicapai dengan ide inti yang dicapai didalam penerapannya setiap hari. TQM menginginkan adanya peningkatan kualitas mutu dijadikan titik tekan inti didalam manajerial serta pembahasan terkait TQM. Juran mengemukakan 3 proses manajerial sebuah organisasi atau institusi yang familiar dengan sebutan trilogy juran:

- Kualitas perencanaan, yang merupakan proses identifikasi customer dan proses tersebutlah yang akan dijadikan patokan produk yang memiliki karakteristik yang tepat dan selanjutnya mentransfer knowledge keseluruh anak 
cabang perusahaan guna tercapainya cutomer satisfaction.

- Kualitas pengendalian, suatu proses yang memperlihatkan bahwa produk selalu dilakukan pemeriksaan dan evaluasi dengan benar, kemudian dibandingkan keinginan dan kebutuhan yang customer. Persoalan yang mungkin muncul dan telah diketahui selanjutnya diselesaikan, contohnya mesin rusak akan segera dilakukan perbaikan.

- Quality improvement. merupakan tata cara yang telah stabil dipertahankan sehingga mutu selalu dapat tercapai secara berkesinambungan. Hal tersebut mencakup pengalokasian sumber-sumber, penugasan sumber daya manusia untuk penyelesaian proyek mutu, pelatihan bagi para karyawan atau pekerja yang terlibat dalam proyek mutu serta selalu mempertahankan mutu yang telah dicapai pada tahapan sebelumnya.

konsep diatas dianggap condong pada pengelolaan keuangan atau sering dikemukakan sebagai urusan finansial, namun tetap dapat diterjemahkan dalam berbagai sektor pendidikan. Pada Intinya dengan adanya pengutamaan tentang begitu pentingnya perbaikan mutu secara berkesinambungan bagi setiap produk meskipun teknik yang digunakan bervariasi. pendekatan holistic TQM adalh kerangka kerja yang menopang manajemen pelayanan, dan kerangka kerja tersebut menurut (Primiani \& Ariani, 2005) meliputi 13 poin yang meliputi (1) kepemimpinan dan budaya kualitas; (2) adanya pengakuan dan reward; (3) full involvement; (4) pendayagunaan informasi untuk analisis; (5) perencanaan strategic; pengembangan SDM melalui studi lanjut dan pelatihan; (7) kepemimpinan terhadap masalah yang sedang dihadapi; manajemen kualitas proses; (9) komitment; (10) kualitas dan hasil operasi; (11) tindakan preventif; (12) team work dan (13) fokus terhadap pelanggan dan kepuasannya.

Onuka (Ejioneueme \& Oyoyo. 2015) menyatakan bahwa TQm memiliki lima komponen utama; 1) Komitmen total terhadap kualitas (kepemimpinan yang fefektif); 2) komitmen total terhadao kepuasan siswa; 3) komitmen total terhadap peningkatan berkelanjutan; 4) komunikasi yang efektif dan 5) kerja tim.

Penelitian ini membahas pengejahwantahan TQM dalam institusi pendidikan baik dijenjang pendidikan dasar, pendidikan menengah dan pendidikan tinggi.

Peningkatan kualitas dari mutu pendidikan disadari atau tidak, diyakini atau tidak selalu terintegrasi dengan proses peningkatan kualitas sumber daya manusia dalam suatu 
bangsa. Pemerintah Indonesia sebagai penangung jawab peningkatan kualitas SDM tetang UU No. 22 tahun 1999 tentang Pemda yang didalamnya memberikan kewenangan kepada daerah untuk menyelanggarakan sekaligus membawa perubahan dan pengeloaan pendidikan ke arah yang lebih baik.

\section{METODE PENELITIAN}

Pendekatan yang dilakukan dalam penelitian ini adalah pendekatan deskriptif kualitatif, dengan menggunakan studi literatur, yang mana hasil dari penelitian tersebut dideskripsikan menggunakan kata-kata dan bahasa. Data yang dikumpulkan berupa uraian atau kalimat dan bukan angkaangka yang mana data olah tersebut dideskripsikan secara runtut sesuai kejadian yang tertulis didalam jurnal yang dikaji. peneliti bertindak sebagai instrumen inti yang merencanakan, melaksanakan, mengumpulkan data, menganalisis data, menarik kesimpulan diakhiri dengan membuat laporan.

Analisis data Bogdan \& Biklen (Moleong, 2005:248) adalah usaha yang dijalankann dengan bekerja dengan data sehingga berakhir dengan penemuan apa yang menjadi titik inti dan important serta apa yang dipelajari kemudian dapat diambil suatu keputusan apa yang dapat dishare kepada khalayak umum. Proses menganalisis data pada artikel ini terdiri dalam beberapa tahap (Anwar, 2018), yaitu: (1) mereduksi data. Data yang dimaksud adalah hasil analisis jurnal terpilih; (2) penyajian data secara naratif dari hasil reduksi data; (3) penarikan kesimpulan yang merupakan pemberian kesimpulan terhadap hasil penafsiran dan evaluasi.

\section{HASIL DAN PEMBAHASAN}

Pendidikan adalah selalu berbicara tentang orang yang belajar. TQM di dunia pendidikan selalu terkait dengan mutu pengalaman siswa. Siswa merupakan pelanggan primer. Tanpa kemampuan dan kemauan untuk memenuhi pendidikan seperti yang dibutuhkan siswa, merupakan hal yang mustahil untuk suatu lembaga pendidikan dikatakan telah mencapai TQM. Di bawah ini akan dipaparkan penerapan TQM di dunia pendidikan, yang dimulai dari pendidikan dasar, Pendidikan menengah dan pendidikan tinggi.

Implementasi TQM di pendidikan Dasar terpaparkan sesuai dengan penelitian pada pendidikan di Distrik Northerm Senatorial, Negara Bagian Ondo. Temuan pada artikel tersebut menunjukkan bahwa baik kepala sekolah maupun guru setuju untuk mengadopsi Team Work terutama dalam mengembangkan visi dan misi sekolah, mempromosikan peningkatan berkelanjutan dan membentuk komite sekolah sebagai 
bentuk peningkatan team work, namun responden tidak setuju jika guru dilibatkan dalam pengambilan keputusan kepala sekolah terutama dalam hal peningkatan berkelanjutan. Hal yang menarik pada penelitian ini terlihat dari banyak kepala sekolah belum mengadopsi sebagian besar praktik pelatihan berkelanjutan misalnya mensponsori guru dalam konferensi, kursus kecakapan TIK bahkan tidak memberikan cuti belajar.

\section{Implementasi TQM di} pendidikan menengah dalam artikel ini berdasarkan penelitian di sekolah menengah di zona Pendidikan Umuahia Nigeria. Pada penelitian tersebut TQM lebih ditekankan kepada komitmen total, Team Work dan Komunikasi yang efektif. Komitmen total dalam penerapan di pendidikan menengah dipandang memiliki peran yang sangat penting karena baik pemimpin maupun bawahan harus dibuat untuk menunjukkan komitmen total terhadap visi dan misi organisasi, dalam penerapannya, kepala sekolah diharapkan untuk mempertahankan peran mereka sebagai fasilitator dan merangkul semua sumber daya sebagai mitra dalam mencapai tujuan bersama. Penerapan Komitmen total pada TQM di Zona Pendidikan Umuahia dipandang cukup tinggi karena kepala sekolah secara aktif terlibat dalam manajemen mutu, kepala sekolah mendorong guru untuk terlibat dalam kegiatan peningkatan kualitas, kepala sekolah memberdayakan guru untuk membantu dalam mencapai tujuan sekolah dan juga ditemukan bahwa guru berkomitmen terhadap pekerjaan mereka. Penerapan team work pada Zona Umuahia dinilai cukup tinggi hal ini terlihat dari kegiatan yang meliputi adanya program pelatihan yang dirancang mempersiapkan individu untuk bekerja secara efektif dalam lingkungan tim, kepala sekolah mendorong team work dengan mendefinisikan visi dan misi sekolah, kepala sekolah memberi kesempatan guru untuk berbagi ide dan pengetahuan mereka, bahkan kepala sekolah mendiring guru dan staf bekerja sebagai sebuah tim. Penerapan komunikasi yang efektif kurang dilakukan pada pendidikan menengah hal ini terlihat dari bagaimana kepala sekolah mengkomunikasikan berbagai kebijakan dan rencana kepada guru dan staf pada batas tertentu dirasa kurang maksimal meskipun kepala sekolah sudah terlihat meminta saran, ide dan informasi kepada guru dan staf.

Implementasi TQM di pendidikan tinggi merujuk pada penelitian yang dilakukan di Najran University. Pada penelitian ini TQM diterjemahkan kedalam 6 dimensi yaitu kepemimpinan yang efektif, membuat keputusan berdasarkan fakta, perencanaan strategis, partisipasi dan team work, fokus 
pada kepuasan pelanggan dan keunggulan yang berkelanjutan. Bedasarkan data yang tekah diolah ditemukan fakta bahwa keseluruhan dimensi tersebut diimplementasikan sebesar $68,4 \%$. Untuk memperjelas penerapan TQM di pendidikan tinggi sebetulnya terlihat dan terwujud dalam pola interaksi dosen dan mahasiswa, atau penciptaan organisasi pembelajar sebagai hasil dari sistem pendidikan yang terukur. Kesulitan penerapan TQM diduga dikarenakan staf belum memahami bagimana elemen-elemen kunci TQM seperti partisipasi aktif mahasiswa, team work dan komunikasi yang efektif

TQM yang telah dijabarkan di atas, merupakan filosofi yang membantu institusi pendidikan terutama untuk mengelola perubahan. Esensi dari TQM adalah perubahan budaya. Perubahan yang terjadi berguna dalam memenuhi kebutuhan dan harapan orang-orang yang terlibat dalam bisnis pendidikan tersebut. Kebutuhan dan harapan tersebut akan dapat terwujud apabila terwujud mutual trust antar pengelola bisnis pendidikan yang dalam hal ini meliputi kepala sekolah, pengajar dan staf akademik. Berdasarkan pemaparan dan penelaahan 3 jurnal dapat ditarik sebuah benang merah bahwa penerapan TQM di dunia pendidikan minimal mencakup 5 indikator yaitu: 1) kepemimpinan yang efektif; 2) fokus pada kepuasan pelanggan; 3) peningkatan kualitas berkelanjutan; 4) komunikasi yang efektif dan 5) team work.

\section{KESIMPULAN}

Berdasarkan hasil analisis data dan pembahasan, dapat disimpulkan bahwa Penerapan TQM di dunia pendidikan minimal mencakup 5 indikator yaitu: 1) kepemimpinan yang efektif; 2) fokus pada kepuasan pelanggan; 3) peningkatan kualitas berkelanjutan; 4) komunikasi yang efektif dan 5) team work.

Berdasarkan kesimpulan tersebut peneliti menyarankan agar TQM dapat dilakukan secara berkelanjutan dan mengasilkan hasil sesuai dengan yang diharapkan maka perlu adanya komitmen dari seluruh elemen sekolah agar program TQM berjalan, yang kedua selalu mempersiapkan SDM yang berkualitas serta ditunjang perumusan value, vission dan mission yang bisa dipahami seluruh elemen sekolah.

\section{REFERENSI}

Al-Din H M K \& Abouzid M M. (2016). Extent of Implementing The Total Quality Management Principles By Academic Departments Heads at najran University From Faculty Members' Perspectives. Journal Of Education And Practice. Vol 7 No 2 tahun 2016.

Anwar, Saiful. (2018). Analisa Timed Based Conflict, Strain 
Cased Conflict dan Behavior Based Conflict Pada Perempuan yang Menjalankan Bisnis Keluarga. Jurnal Pekobis Vol. 3 No 2 Oktober 2018.

Babatande E G \& Victor A A. (2018). Total Quality Magement (TQM) Practices Adopted By Head Teachers For Sustainable Primary Education In Northerm Senatorial District of Ondo State, Nigeria. EPRA International Journal Of Multidisclplinary Research. Vol, 4 Issue \& Juli 2018.

Ejionueme L K \& Oyoyo A O. (2015). Application Of Total Quality Management (TQM) in Secondary School Administration In Umuahia Education Zone. Journal Of Education And Practice Vol 6 No 27 Tahun 2015.

Moleong, Lexy J. (2005). Metodologi Penelitian Kualitatif. Edisi Revisi. Bandung: PT Remaja Rosdakarya.

Praboeo, Suto. (2012). Total Quality Manajemen dalam Pendidikan. Jurnal Sosial Humaniora Vool 5 No 1 tahun 2012 Halaman 72-77. Primiani, C, N \& Ariani, D, W. (2005). Total Quality Management dan Service Quality dalam Organisasi Pendidikan Tinggi. Jurnal Cakrawala Pendidikan. Juni 2015 Th. XXIV No. 2. Halaman 177-196.

Sallis. Edward. (2006). Total Quality Management in Education,
Manajemen Mutu Pendidikan. Jogjakarta: IRCiSoD 